\title{
PENGARUH TRUST DAN EASY OF USE TERHADAP MINAT BELI ULANG PADA MARKETPLACE SHOPEE DI KOTA MATARAM
}

\author{
I Gusti Agung Ayu Alit Masarianti Putri*) \\ Sri Darwini**) \\ Muhammad Mujahid Dakwah $\left.{ }^{* * *}\right)$
}

\begin{abstract}
This research entitled the influence of Trust and Easy Of Use on Repurchase Interests in the Shopee Marketplace in the City of Mataram. The purpose of this research is to examine the influence of Trust and Easy Of Use on Repurchase Interests in Shopee Marketplace in Mataram Mataram City or associative. The study was conducted on a sample of consumers who had conducted transactions at the Shopee marketplace with 50 respondents with criteria for consumer samples aged 16 to 40 years, having access to applications or websites from the Shopee marketplace and having the desire to shop online at the Shopee marketplace. Data were then analyzed using multiple regression analysis.

The results of the research show that the trust variable influences the repurchase intention positively but not significantly. And the results of the easy of use variable have a positive and significant repurchase intention.
\end{abstract}

Key Words: Trust, Easy Of Use, Repurchase Interests, Marketplace

\section{Pendahuluan}

Perkembangan zaman yang didukung dengan perkembangan teknologi saat ini memudahkan manusia dalam setiap kegiatan, contohnya berbelanja. Sehingga perusahaan harus memperhatikan peluang kemajuan teknologi dan lebih mengoptimalkan fasilitas teknologi informasi dan komunikasi yang berkembang dalam rangka dapat bertahan dan menang dalam persaingan usaha di pasar global. Tingginya penggunaan internet di Indonesia pula dimanfaatkan oleh banyak orang sebagai peluang bisnis yang menjanjikan.

Data hasil survey pengguna internet di Indonesia tahun 2017 yang dilakukan oleh Asosiasi Penyelenggara Jasa Internet Indonesia ( APJII). Jumlah populasi penduduk Indonesia saat ini mencapai 262 juta orang. Tercatat dalam survey sekitar 54,68 persen atau sekitar 143,26 juta orang telah terhubung jaringan internet sepanjang 2017 (tekno.kompas.com). Dengan jumlah pengguna internet demikian, pasar e-commerce menjadi tambang emas bagi sebagian orang yang bergerak dalam industri perdagangan untuk bisa melihat potensi dan memanfaatkan peluang dalam berbisnis dengan memanfaatkan jasa jaringan internet yang sedang berkembang di Indonesia .

Saat ini sudah banyak situs e- commerce yang menyediakan akses mobile untuk memudahkan kegiatan berbelanja tanpa harus berpergian keluar rumah. Kondisi tersebut merupakan salah satu wujud dari perkembangan teknologi di bidang bisnis. Marketplace merupakan salah satu wujud dari perkembangan teknologi tersebut dimana marketplace merupakan model bisnis dimana website atau aplikasi dibuat tidak hanya membantu mempromosikan barang dagangan saja, tapi juga memfasilitasi transaksi uang secara online. Pada sistem belanja online ini, sebuah website atau aplikasi menyediakan lahan atau tempat bagi para penjual untuk menjual produk-produknya. Di website atau aplikasi inilah kita akan menemukan produk dari penjual yang berbeda.

\footnotetext{
*) Fakultas Ekonomi dan Bisnis Unram, Email : agungayualit17@gmail.com

${ }^{* *}$ Fakultas Ekonomi dan Bisnis, Email : sridarwini@unram.ac.id

${ }^{* * *}$ Fakultas Ekonomi dan Bisnis, Email : mujahid.fe@unram.ac.id
} 
Marketplace yang berkembang di Indonesia, diantaranya adalah Tokopedia, Buka Lapak, Shopee, Lazada, Blibli, JD.ID, Sale Stock Indonesia, Elevenia, Bhinneka, Zalora dan lain sebagainya. Tokopedia memegang rating tertinggi pengunjung bulanan setelah itu Bukalapak dan Shopee. Shopee memegang rating tertinggi dalam jumlah download aplikasi dan terpopuler (iprice.co.id 2018).

Salah satu market place yang populer di Indonesia saat ini adalah Shoope. Shopee adalah salah satu pusat perbelanjaan yang dikelola oleh Garena (berubah nama menjadi SEA Group). Bisnis C2C (customer to customer) mobile marketplace yang diusung. Shopee Indonesia resmi diperkenalkan di Indonesia pada Desember 2015 di bawah naungan PT Shopee International Indonesia. Sejak peluncurannya, Shopee Indonesia mengalami perkembangan yang sangat pesat, bahkan hingga Oktober 2017 aplikasinya sudah didownload oleh lebih dari 43 juta pengguna (wikipedia.org 2018).

Hal utama yang menjadi pertimbangan seorang pembeli dalam berbelanja online adalah apakah mereka memiliki kepercayaan (trust) kepada website yang menyediakan online shopping dan penjual online pada website tersebut. Kepercayaan pembeli terhadap website online shopping terletak pada popularitas website online shopping tersebut. Semakin popularitas suatu website, maka pembeli lebih yakin dan percaya terhadap website tersebut. Selanjutnya, kepercayaan pembeli terhadap penjual online terkait dengan keandalan penjual online dalam menjamin keamanan bertransaksi dan meyakinkan transaksi akan diproses setelah pembayaran dilakukan oleh pembeli. Keandalan ini terkait dengan keberadaan penjual online. Semakin berkembangnya teknologi, semakin berkembang pula modus penipuan berbasis teknologi pada online shopping. Oleh karna itu rasa percaya antara pelanggan dengan penjual perlu dipelihara guna menjaga hubungan dengan pelanggan. Selain itu kemudahan penggunaan (easy of use) pula memiliki pengaruh terhadap seseorang berbelanja secara online. Davis dalam Nasution (2004:5) mendefinisikan kemudahan penggunaan (ease of use) merupakan suatu tingkatan kepercayaan seseorang bahwa komputer dapat dengan mudah dipahami. Ketika konsumen merasakan kemudahan dalam berinteraksi dengan situs web e-commerce, untuk mencari produk dan membayar online, mereka akan merasakan kenyamanan dalam berbelanja online. Hal ini nantinya akan menimbulkan kepercayaan pelanggan dan akhirnya akan tercipta kesetiaan pelanggan. Setelah seseorang memiliki kepercayaan (trust) dan kemudahan dalam penggunaan (ease of use) aplikasi atau website dari marketplace dalam bertransaksi secara online maka akan tercipta loyalitas konsumen. Bentuk dari loyalitas konsumen yaitu salah satunya keinginan atau minat pembelian ulang.

Berdasarkan pentingnya kepercayaan dan kemudahan penggunaan dapat mempengaruhi minat beli ulang maka perlu dilakukan penelitian tentang faktor-faktor tersebut dalam mempengaruhi minat beli ulang secara online, oleh karena itu peneliti tertarik untuk meneliti pengaruh yang terjadi antar variabel dengan judul "Pengaruh Trust dan Easy Of Use terhadap Minat Beli Ulang pada Marketplace Shopee di Kota Mataram".

\section{Tinjauan Teoritis}

\subsection{Teori E- Commerce}

Menurut Varmaat, Shelly Cashman (2007) E-commerce atau kependekan dari elektronic commerce (perdagangan secara elektronik), merupakan transaksi bisnis yang terjadi dalam jaringan elektronik, seperti internet. Menurut Turban (2011:48) e-commerce adalah proses pembelian, penjualan atau pertukaran produk, jasa dan informasi melalui jaringan komputer. E-commerce merupakan bagian dari e-business, di mana cakupan e-business lebih luas, tidak hanya sekedar perniagaan tetapi mencakup juga mengkolaborasian mitra bisnis, pelayanan nasabah, lowongan pekerjaan dan lain-lain. Selain teknologi jaringan www, e-commerce juga memerlukan teknologi basis data atau pangkalan data (database), e- 
surat atau surat elektronik (e-mail), dan bentuk teknologi non komputer yang lain seperti halnya sistem pengiriman barang, dan alat pembayaran untuk e-commerce ini. Sedangkan menurut Wong, Jony (2010) perdagangan elektronik atau $e$-commerce adalah pembelian, penjualan dan pemasaran barang serta jasa melalui sistem elektronik. Seperti televisi, radio dan jaringan komputer atau internet.

\subsection{Teori Marketplace}

Menurut Assadurachman (2017) Marketplace adalah media online berbasis internet (web based) tempat melakukan kegiatan bisnis dan transaksi antara pembeli dan penjual. Pembeli dapat mencari supplier sebanyak mungkin dengan kriteria yang diinginkan, sehingga memperoleh sesuai harga pasar. Menurut Brunn dkk. (2002), Marketplace adalah sebuah tempat dari komunitas bisnis interaktif secara elektronik yang menyediakan suatu wadah jual beli, dimana perusahaan dapat ambil andil dalam B2B e-commerce atau kegiatan ebusiness lain. Menurut Brunn dkk (2002), Marketplace dibagi menjadi 2 kategori, yaitu

a. Marketplaces vertical. Marketpalces vertical, adalah kategori dari sebuah pasar elektronik yang menyediakan kebutuhan khusus atau sejenis yang biasanya menyediakan kebutuhan suatu bahan industri seperti : baja, beton, semen dan bahan yang lain dalam jumlah banyak. Atau bahkan marketplace yang menyediakan barang dengan jenis tertentu seperti baru atau bekas.

b. Marketplaces Horizontal. Marketplaces horizontal, adalah kategori dari sebuah pasar elektronik yang menyediakan kebutuhan umum atau beragam seperti : smartphone, pc(personal computer), baju dan barang umum lainnya seperti layaknya di pusat perbelanjaan, namun dengan biaya transaksi yang lebih rendah.

\subsection{Minat beli ulang}

Menurut Wijaya dalam Apriyani dan Suharti (2017:24) Minat beli ulang merupakan bagian dari perilaku pembelian konsumen di mana kesesuaian antara performa dari produk atau jasa yang ditawarkan perusahaan menghasilkan minat konsumen untuk mengkonsumsinya lagi di masa yang akan datang. Kotler dan Keller (2009: 244) berpendapat bahwa setelah konsumen membeli produk tersebut, konsumen bisa puas atau tidak puas dan terlibat dalam perilaku pasca pembelian. Pelanggan yang puas akan kembali membeli produk, memuji produk yang membelinya dihadapan orang lain, sedikit menarik perhatian pada merek dan iklan pesaing dan membeli produk lain dari perusahaan yang sama.

Adapun indikator minat pembelian ulang menurut Ferdinand dalam Hartanto, Riadi (2018) antara lain yaitu:

a. Minat Transaksional

Kecenderungan konsumen untuk selalu membeli ulang produk atau jasa yang telah dikonsumsinya.

b. Minat Referensial

Kesediaan atau kecendrungan seseorang untuk merefrensikan produk yang sudah dibelinya, agar juga dibeli oleh orang lain dengan referensi pengalaman konsumsinya untuk merekomendasikan produk atau jasa yang telah dikonsumsinya kepada orang lain.

c. Minat Preferensial

Minat yang menggambarkan perilaku seseorang yang selalu memiliki referensi utama pada produk yang telah dikonsumsi. Preferensi ini hanya dapat diganti bila terjadi sesuatu dengan produk preferensinya. 


\section{d. Minat Eksploratif}

Minat ini menggambarkan perilaku seseorang yang selalu mencari informasi mengenai produk yang diminatinya dan mencari informasi untuk mendukung sifat-sifat positif dari produk tersebut.

\subsection{Kepercayaan (Trust)}

Menurut Rahmawari dalam Norhermaya, Y.A., dan Harry Soesanto (2016), Kepercayaan (trust) merupakan pondasi utama dari suatu bisnis. Suatu transaksi bisnis antara dua pihak atau lebih akan terjadi apabila masing-masing saling mempercayai satu sama lain. Kepercayaan pelanggan akan e- commerce merupakan salah satu faktor kunci melakukan kegiatan jual beli secara online. Menurut Mowen dan Minor (2002) kepercayaan (trust) konsumen mengandung arti bahwa semua pengetahuan yang dimiliki oleh konsumen dan semua kesimpulan yang dibuat oleh konsumen mengenai objek, atribut dan manfaatnya. Menurut Mayer dalam Ainurrofiq (2007) indikator yang membentuk kepercayaan seseorang antara lain ada tiga yaitu kemampuan (ability), integritas (integrity) dan kebaikan hati (benevolence). Ketiga indikator tersebut dapat dijelaskan sebagai berikut:

a. Kemampuan (Ability).

Kemampuan mengacu pada kompetensi dan karakteristik penjual/organisasi dalam mempengaruhi dan mengotorisasi wilayah yang spesifik. Dalam hal ini, bagaimana penjual mampu menyediakan, melayani, sampai mengamankan transasksi dari gangguan pihak lain. Artinya bahwa konsumen memperoleh jaminan kepuasan dan keamanan dari penjual dalam melakukan transaksi. Kepercayaan adalah ranah khusus, sehingga individu membutuhkan keyakinan akan seberapa baik seseorang mempelihatkan performanya. Faktor pengalaman dan pembuktian performanya akan mendasari munculnya kepercayaan orang lain terhadap individu.

b. Integritas (Integrity).

Integritas berkaitan dengan bagaimana perilaku atau kebiasaan penjual dalam menjalankan bisnisnya. Informasi yang diberikan kepada konsumen apakah benar sesuai dengan fakta atau tidak. Kualitas produk yang dijual apakah dapat dipercaya atau tidak. Integritas terlihat dari konsistensi antara ucapan dan perbuatan dengan nilai-nilai diri seseorang.

c. Kebaikan hati (Benevolence).

Kebaikan hati merupakan kemauan penjual dalam memberikan kepuasan yang saling menguntungkan antara dirinya dengan konsumen. Kebaikan hati berkaitan dengan intensi (niat). Ada ketertarikan dalam diri seseorang ketika berinteraksi dengan orang lain. Hal tersebut akan mengarahkannya untuk memikirkan orang tersebut dan memberikan intense untuk percaya atau tidak dengan orang tersebut.

\subsection{Kemudahan pengunaan (Easy Of Use)}

Davis dalam Nasution (2004:5) mendefinisikan kemudahan penggunaan (ease of use) sebagai suatu tingkatan dimana seseorang percaya bahwa komputer dapat dengan mudah dipahami. Berdasarkan definisi di atas dapat disimpulkan bahwa kemudahan penggunaan akan mengurangi usaha (baik waktu dan tenaga) seseorang didalam mempelajari computer. Menurut Jogiyanto, Hartono (2007) persepsi kemudahan penggunaan (ease of use) didefinisikan sebagai sejauh mana seseorang percaya menggunakan suatu teknologi akan bebas dari usaha. Jika pengguna atau seseorang yang menganggap suatu sistem informasi mudah digunakan maka mereka pun akan menggunakan sistem informasi tersebut, sebaliknya jika suatu sistem informasi dirasa sulit digunakan mereka pun tak akan menggunakan suatu sistem informasi tersebut. Persepsi kemudahan penggunaan ini akan berdampak pada perilaku, yaitu semakin tinggi persepsi seseorang tentang 
kemudahan menggunakan sistem, semakin tinggi pula tingkat pemanfaatan teknologi informasi.

Menurut Davis dkk. dalam Jogiyanto (2007:152) terdapat enam indikator kemudahan penggunaan, yaitu :

a. Easy to learn, suatu aplikasi harus mudah untuk dipelajari sehingga pengguna mampu dengan mudah beradapatasi atau memahami aplikasi tersebut.

b. Controllable, suatu aplikasi harus mudah dikendalikan atau dikontrol. Artinya aplikasi dapat digunakan sesuai kebutuhan pengguna.

c. Clear and Understandable, suatu aplikasi harus jelas dan dapat dipahami, baik dari segi konten maupun istilah yang digunakan.

d. Flexible, suatu aplikasi harus fleksibel. Artinya aplikasi dapat disesuaikan dan digunakan kapanpun sesuai keinginan pengguna.

e. Easy to become Skillful, suatu aplikasi harus mudah dimengerti, sehingga pengguna mudah untuk menguasai penggunaan aplikasi tersebut.

f. Easy to use, suatu aplikasi harus mudah untuk digunakan, sehingga pengguna tidak merasa kesulitan dalam pengoperasiannya.

\section{Penelitian Terdahulu}

1. Penelitian yang sebelumnya pernah dilakukan oleh Prasetyo, Sony Agung pada tahun 2015 dengan judul "Analisis Faktor - Faktor yang Mempengaruhi Kepercayaan Serta Dampaknya Terhadap Minat Beli Ulang". Penelitian ini bertujuan untuk mengetahui apakah kemenarikan iklan, kemudahan berbelanja berpengaruh pada kepercayaan konsumen sehingga berdampak pada minat beli ulang pada situs OLX.co.id. Jumlah sampel yang digunakan pada penelitian ini adalah 385 orang yang pernah melakukan pembelian produk melalui situs OLX.co.id. Kuesioner didistribusikan pada bulan Maret 2015 hingga April 2015. Data yang diperoleh kemudian diolah menggunakan analisis regresi berganda. Hasil penelitian menjunjukkan bahwa kedua variabel independen berpengaruh positif dan signifikan terhadap variabel kepercayaan. Variabel kemenarikan iklan berpengaruh paling besar terhadap variabel kepercayaan dan pengaruh tidak langsung terhadap minat beli ulang. Sama seperti penelitian sebelumnya, kepercayaan memiliki pengaruh yang positif dan signifikan terhadap variabel minat beli ulang dan berperan sebagai variabel intervening.

2. Penelitian yang dilakukan oleh Hartanto, Riadi (2018) dengan judul "Analisis Pengaruh Kemudahan Penggunaan, Harga, dan Kualitas Pelayanan Terhadap Minat Pembelian Ulang Jasa Transportasi Online pada Mahasiswa Fakultas Ekonomi dan Bisnis Universitas Sumatera Utara Medan". Penelitian ini bertujuan untuk menganalisis pengaruh kemudahan penggunaan, harga, dan kualitas pelayanan terhadap minat pembelian ulang layanan jasa transportasi online pada mahasiswa Fakultas Ekonomi dan Bisnis Universitas Sumatera Utara. Pengambilan sampel dalam penelitian ini menggunakan teknik nonprobability sampling, dan menggunakan metode snowball sampling. Jenis data yang digunakan dalam penelitian ini adalah data primer dengan cara menyebarkan kuisioner secara langsung kepada konsumen. Jumlah Sampel dalam penelitian ini adalah sebanyak 97 orang. Metode yang digunakan dalam penelitian ini meliputi uji validitas, uji reliabilitas, analisis deskriptif, analisis regresi linear berganda, uji asumsi klasik yang meliputi uji normalitas, uji heteroskedastisitas, dan uji multikolinearitas, uji hipotesis yang meliputi uji $\mathrm{F}$, uji $\mathrm{t}$, dan uji koefisien determinasi serta uji beda. Hasil dari penelitian ini menunjukkan bahwa kemudahan penggunaan, harga, dan kualitas layanan secara simultan berpengaruh positif dan signifikan terhadap minat pembelian ulang layanan jasa transportasi online pada mahasiswa Fakultas Ekonomi dan Bisnis Universitas Sumatera Utara Medan. 
3. Norhermaya, Y.A., dan Harry Soesanto pada tahun 2016 melakukan penelitian dengan judul "Analisis Pengaruh Kepuasan Pelanggan Terhadap Kepercayaan dan Loyalitas Pelanggan untuk Meningkatkan Minat Beli Ulang (Studi Pada Online Store Lazada.Co.Id)". Penelitian ini bertujuan untuk menganalisis pengaruh kepuasan pelanggan terhadap kepercayaan dan loyalitas pelanggan untuk meningkatkan minat beli ulang pelanggan Lazada.co.id. Populasi dalam penelitian ini adalah pelanggan Lazada.co.id yang telah melakukan pembelian lebih dari 3 kali. Teknik analisis yang digunakan dalam penelitian ini adalah Structural Equation Model (SEM) yang dioperasikan melalui program AMOS 22.0. Alasan penggunaan SEM, karena SEM merupakan sekumpulan teknik statistik yang memungkinkan pengukuran sebuah rangkaian hubungan yang relatif rumit secara simultan dan dengan pengujian hipotesis yang diajukan dalam penelitian ini didasarkan pada nilai Critical Ratio (CR) dari suatu hubungan kausalitas.. Hasil dari penelitian ini menunjukkan bahwa kepuasan pelanggan berpengaruh positif dan signifikan pada kepercayaan.

\section{Kerangka Konseptual}

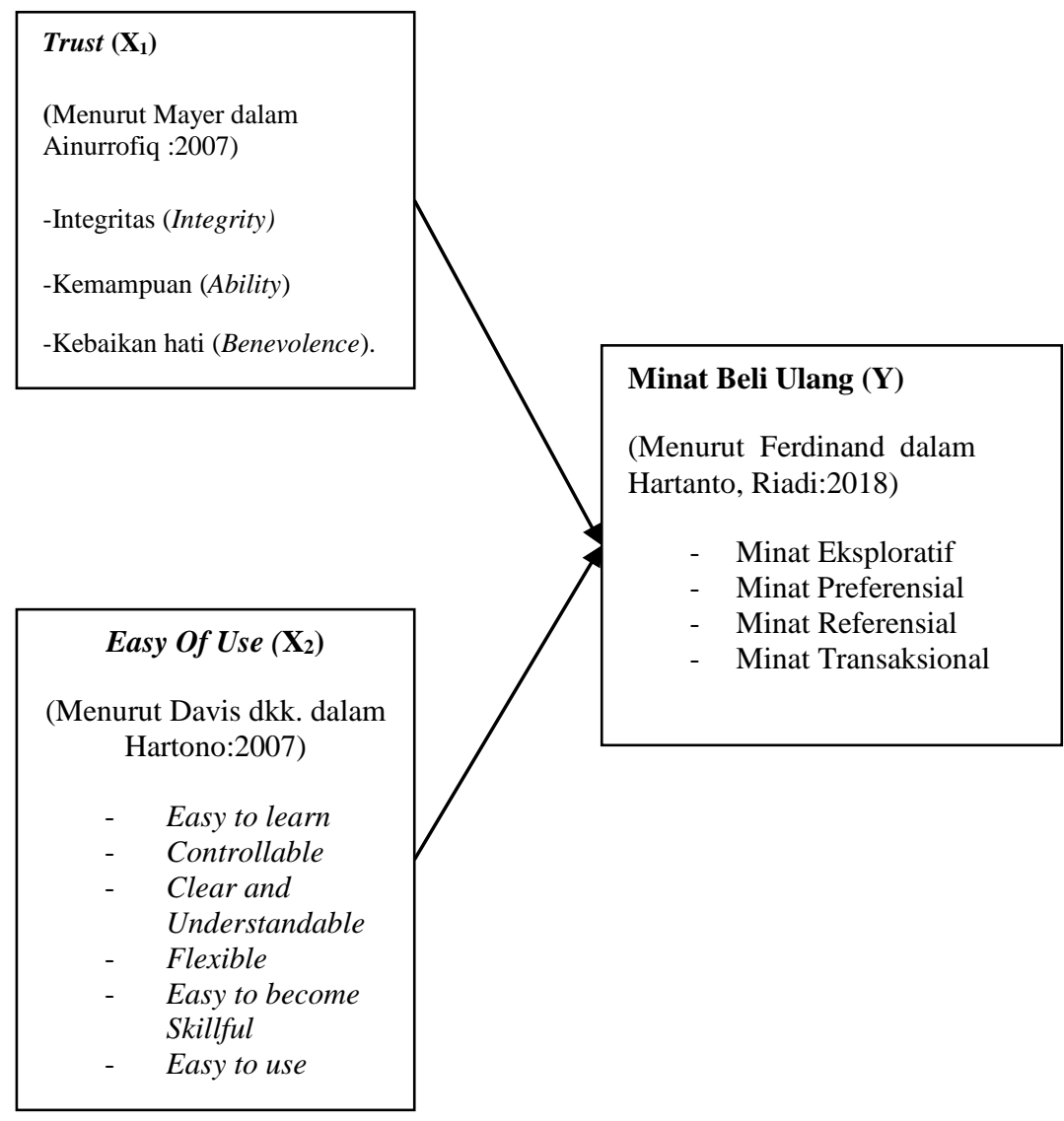

Berdasarkan hubungan antar variabel kerangka konseptual di atas maka peneliti merumuskan hipotesis sebagai berikut :

H1 : Diduga Kepercayaan (Trust) Berpengaruh Signifikan Terhadap Minat Beli Ulang.

H2 : Diduga Kemudahan Penggunaan (Easy Of Use) Berpengaruh Signifikan Terhadap Minat Beli Ulang. 


\section{Metode Penelitian}

Penelitian ini merupakan penelitian asosiatif. Lokasi penelitian di Kota Mataram pada November 2018 sampai dengan Februari 2019. Populasi dalam penelitian ini adalah konsumen yang pernah melakukan transaksi pembelian secara online dan memiliki keinginan untuk melakukan pembelian ulang pada marketplace Shopee di Kota Mataram, Nusa Tenggara Barat. Dengan 50 sampel dan teknik pengambilan Sampel yaitu Purposive Sampling di penelitian dikarenakan peneliti ingin memilih sampel dari konsumen yang pernah melakukan transaksi pembelian secara online di marketplace Shopee lebih dari satu kali, memiliki keinginan untuk berbelanja online kembali di marketplace Shopee, memiliki akses transaksi marketplace Shope baik website maupun aplikasi, dan konsumen Shopee yang memiliki umur sekitar 16 sampai dengan 40 tahun.

\section{Hasil Dan Pembahasan}

Shopee yang berdiri pada tanggal 1 Desember 2015 di bawah naungan PT Shopee International Indonesia. Sejak peluncurannya, Shopee Indonesia mengalami perkembangan yang sangat pesat, bahkan hingga Oktober 2017 aplikasinya sudah didownload oleh lebih dari 43 juta pengguna. Shopee merupakan salah satu dari banyak pihak yang memanfaatkan peluang perkembangan teknologi informasi di Indonesia dengan menerapkan bisnis C2C (customer to customer) mobile marketplace melalui aplikasi dan website mereka untuk mempermudah transaksi jual beli melalui perangkat ponsel dengan menyediakan online marketplace yang menjembatani penjual dan pembeli untuk mempermudah transaksi jual beli online melalui perangkat ponsel.

Sebagai perusahaan yang bergerak di bidang mobile application dan website untuk online shopping, Shopee memberi pilihan para penggunanya untuk bisa membeli barang dari berbagai penjual tanpa khawatir terhadap penipuan yang kerap terjadi pada online shopping karena Shopee memastikan keamanan sejumlah uang yang ditransfer pembeli akan ditahan oleh pihak Shopee dan akan diberikan kepada pihak penjual ketika pembeli sudah menerima barang yang dipesan. Selain itu Shopee juga memiliki promo - promo menarik dan kelengkapan fitur dan produk yang membuat marketplace ini semakin dikenal dan disukai oleh berbagai kalangan. Salah satunya yaitu subsidi gratis ongkos kirim dan berbagai cashback berbelanja pada marketplace Shopee. Shopee menerapkan sistem layanan jual beli interaktif antara penjual dan pembeli melalui fitur live chat. Shopee menyediakan berbagai sistem pembayaran melalui transfer bank, Indomaret, Kredivo, hingga kartu kredit. Selain itu, tersedia juga dompet elektronik, Shopee Pay yang dapat menyimpan seluruh dana, baik dari penjualan atau pembelian. Shopee berkerjasama dengan beberapa jasa logistik seperti JNE, J\&T Express, GO-JEK (Go-Send), dan Pos Indonesia untuk membantu proses pengiriman barang. Shopee juga mendapat banyak penghargaan diantaranya Netizen Brand Choice Award, Marketing Award,Bright Awards Indonesia 2017 dan 10 Iklan Terpopuler versi Youtube Indonesia.

Penelitian ini secara umum menggunakan data primer yang diperoleh langsung dari responden. Pengambilan data pada responden dilakukan melalui wawancara langsung kepada calon responden lalu memberikan daftar pernyataan kuesioner kepada calon responden yang memenuhi syarat atau kriteria responden yang sudah ditentukan. Selain menyebarkan kuesioner secara manual, peneliti juga memanfaatkan teknologi Google Form untuk mendapatkan responden. Kriteria atau syarat menjadi reponden terlampir pada halaman awal kuesioner online yang diantaranya yaitu reponden harus berusia diantara 16 sampai dengan 40 tahun, pernah melakukan transaksi pada marketplace Shopee, memiliki akses baik aplikasi atau website shopee, memiliki keinginan untuk berbelanja kembali pada marketplace shopee dan masyarakat yang berdomisili di Kota Mataram sebagai responden peneliti. Data yang berhasil dikumpulkan dengan menyebarkan kuesioner secara langsung 
dan online terhitung sejak tanggal 24 Desember 2018 sampai dengan 20 Januari 2019. Setelah peneliti mendapatkan jumlah sampel sesuai dengan yang dibutuhkan, maka penyebaran kuesioner selesai dilakukan. Sedangkandata sekunder diperoleh dari buku buku referensi yang berkaitan dengan penelitian dan merupakan data pendukung untuk lebih mengarahkan pada tujuan penelitian.

Berdasarkan hasil penelitian yang dilakukan terhadap 50 responden yairu konsumen yang pernah melakukan transaksi pembelian secara online di marketplace Shopee lebih dari satu kali, memiliki akses baik aplikasi atau website shopee, memiliki keinginan untuk berbelanja online kembali di marketplace Shopee dan konsumen Shopee yang memiliki umur sekitar 16 sampai dengan 40 tahun dan berdomisili di Kota Mataram. Gambaran umum mengenai karakteristik dasar responden yang ditanyakan adalah jenis kelamin, pendidikan terakhir, pekerjaan dan pendapatan. Selain itu karakteristik responden berdasarkan tingkat lebih menyukai berbelanja online dibandingkan toko retail, frekuensi transaksi pada marketplace Shopee, dan jenis produk yang sering dibeli secara online responden marketplace Shopee. Untuk menganalisis variabel trust dan easy of use mempunyai pengaruh terhadap variabel minat beli ulang yaitu dengan menggunakan Regresi Linear Berganda. Tabel 1 adalah tabel hasil dari perhitungan regresi linier berganda.

Tabel 1. Hasil Perhitungan Regresi Linier Berganda

\section{Coefficients $^{\mathrm{a}}$}

\begin{tabular}{|c|c|c|c|c|c|c|}
\hline \multirow{2}{*}{\multicolumn{2}{|c|}{ Model }} & \multicolumn{2}{|c|}{ Unstandardized Coefficients } & \multirow{2}{*}{$\begin{array}{c}\begin{array}{c}\text { Standardized } \\
\text { Coefficients }\end{array} \\
\text { Beta }\end{array}$} & \multirow[b]{2}{*}{$\mathrm{T}$} & \multirow[b]{2}{*}{ Sig. } \\
\hline & & B & Std. Error & & & \\
\hline \multirow[t]{3}{*}{1} & (Constant) & -3.728 & 3.695 & & -1.009 & .318 \\
\hline & KEPERCAYAAN & .202 & .110 & .238 & 1.838 & .072 \\
\hline & $\begin{array}{l}\text { KEMUDAHAN } \\
\text { PENGGUNAAN }\end{array}$ & .565 & .151 & .484 & 3.742 & .000 \\
\hline
\end{tabular}

a. Dependent Variable: MINAT BELI ULANG

Sumber : Data primer diolah tahun 2019

Dari tabel di atas maka dapat dirumuskan regresi linier berganda dengan persamaan sebagai berikut :

$$
Y=-3,728+0,202 X_{1}+0,565 X_{2}+e
$$

$\mathrm{Y}$ adalah minat beli ulang, $\mathrm{X}_{1}$ adalah trust, $\mathrm{X}_{2}$ adalah easy of use dan e adalah error.

Dari persamaan diatas, dapat dianalisis beberapa hal antara lain :

1. Nilai konstanta pada persamaan tersebut sebesar -3,728. Ini artinya bahwa apabila kedua variabel (Trust dan Easy Of Use) dianggap konstan, maka nilai dari minat beli ulang terhadap marketplace Shopee adalah sebesar -3,728. atau bisa dibilang tidak ada minat beli ulang karena nilai tersebut sangat rendah.

2. Koefisien regresi untuk variabel Trust $\left(X_{1}\right)$ sebesar 0,202 , bermakna bahwa jika terjadi peningkatan pada variabel Trust sebesar $100 \%$ maka akan terjadi peningkatan juga pada minat beli ulang sebesar 20,2\% dengan asumsi variabel easy of use tetap atau tidak mengalami perubahan.

3. Koefisien regresi untuk variabel easy of use $\left(X_{2}\right)$ sebesar 0,565 , bermakna bahwa jika terjadi peningkatan pada variabel easy of use sebesar $100 \%$ maka akan terjadi peningkatan juga pada minat beli ulang sebesar 56,5\% dengan asumsi variabel trust tetap atau tidak mengalami perubahan.

Untuk mengetahui tingkat kelayakan model yang tinggi variabel-varibel yang digunakan model mampu untuk menjelaskan fenomena yang dianalisis maka dilakukan uji kelayakan model atau uji $\mathrm{F}$ dengan hasil sebagai berikut: 
Tabel 2. Hasil Uji F

ANOVA $^{b}$

\begin{tabular}{|ll|r|r|r|r|r|}
\hline Model & & Sum of Squares & Df & Mean Square & F & Sig. \\
\hline 1 & Regression & 129.971 & 2 & 64.986 & 15.932 & $.000^{\mathrm{a}}$ \\
Residual & 191.709 & 47 & 4.079 & & \\
Total & 321.680 & 49 & & & \\
\hline
\end{tabular}

a. Predictors: (Constant), KEMUDAHAN PENGGUNAAN,

KEPERCAYAAN

b. Dependent Variable: MINAT BELI ULANG

Sumber : Data primer diolah tahun 2019

Berdasarkan tabel 2. diatas terlihat nilai $\mathrm{F}$ hitung sebesar 15,932 dengan probabilitas signifikan yang menunjukkan nilai sebesar 0,000 itu berarti nilai probabilitas signifikan < 0,05 . Sedangkan hasil yang diperoleh dari $F$ tabel dengan $\mathrm{df} 1=2$ dan $\mathrm{df} 2=47$ pada $\mathrm{a}=0,05$ adalah sebesar 3,20 yang berarti F hitung > F tabel $(15,932>3,20)$ maka dapat disimpulkan bahwa semua variabel independen (trust dan easy of use) layak untuk menjelaskan variabel dependen yang dianalisis.

Uji $\mathrm{t}$ atau uji pengaruh kausalitas adalah uji yang dilakukan terhadap hipotesis kausalitas yang dikembangkan dalam model persamaan regresi. Uji $t$ digunakan untuk melihat signifikansi pengaruh masing-masing variabel antara variabel trust $\left(\mathrm{X}_{1}\right)$ dan easy of use $\left(\mathrm{X}_{2}\right)$ terhadap minat beli ulang $(\mathrm{Y})$ pada marketplace Shopee di Kota Mataram.

Berikut hasil perhitungan $t_{\text {hitung }}$ serta tingkat signifikansi masing-masing variabel $X$ terhadap variabel Y.

Tabel 3. Rekapitulai Hasil Perhitungan $t_{\text {hitung }}$ dan Signifikansi Masing-Masing Variabel Bebas $(X)$ terhadap Variabel Terikat $(Y)$

\begin{tabular}{|l|l|l|l|}
\hline \multicolumn{1}{|c|}{ Variabel } & \multicolumn{1}{c|}{ thitung } & \multicolumn{1}{c|}{ Signifikansi } & \multicolumn{1}{c|}{ Keterangan } \\
\hline Trust $\left(\mathrm{X}_{1}\right)$ & 1,838 & 0,072 & Tidak signifikan \\
\hline Easy Of Use $\left(\mathrm{X}_{2}\right)$ & 3,742 & 0,000 & Signifikan \\
\hline
\end{tabular}

Sumber : Data primer diolah tahun 2019

Pada tabel di atas akan dijelaskan dari kedua variabel bebas yang akan membuktikan signifikan atau tidaknya masing-masing variabel bebas tersebut, dapat dijelaskan sebagai berikut :

1. Pengaruh Trust Terhadap Minat Beli Ulang

Dari Tabel 3. terlihat bahwa hasil pengujian hipotesis variabel trust menunjukkan nilai $t_{\text {hitung }}$ sebesar 1,838 yang lebih besar dari nilai $t_{\text {tabel }}=1,677$. Dengan demikian dapat disimpulkan bahwa variabel trust berpengaruh secara positif namun tidak signifikan terhadap minat beli ulang karena dilihat dari nilai signifikansi 0,072 yang lebih besar dari 0,05 .

2. Pengaruh Easy Of Use Terhadap Minat Beli Ulang

Dari Tabel 3. terlihat bahwa hasil pengujian hipotesis variabel easy of use menunjukkan nilai $t_{\text {hitung }}$ sebesar 3,742 yang lebih besar dari nilai $t_{\text {tabel }}=1,677$. Dengan demikian dapat disimpulkan bahwa variabel easy of use berpengaruh secara positif dan signifikan terhadap minat beli ulang dilihat dari nilai signifikansi 0,000 yang lebih kecil dari 0,05.

Koefisien determinasi ditunjukkan oleh angkat $R$-Square dalam model summary yang dihasilkan oleh program. Nilai $R^{2}$ adalah antara nol dan satu. 
Tabel 4. Hasil Koefisien Determinasi $\left(\mathbf{R}^{2}\right)$ Model Summary

\begin{tabular}{|l|r|r|r|r|}
\hline Model & \multicolumn{1}{|c|}{$\mathrm{R}$} & R Square & $\begin{array}{c}\text { Adjusted R } \\
\text { Square }\end{array}$ & $\begin{array}{c}\text { Std. Error of } \\
\text { the Estimate }\end{array}$ \\
\hline 1 & $.636^{\mathrm{a}}$ & .404 & .379 & 2.01963 \\
\hline
\end{tabular}

a. Predictors: (Constant), KEMUDAHAN PENGGUNAAN, KEPERCAYAAN

Sumber : Data primer diolah tahun 2019

Pada tabel 4. nilai $\mathrm{R}$ diketahui sebesar 0,636, maka koefisien determinasi ( $\mathrm{R}$ Square) adalah sebesar $0,636 \times 0,636=0,404$ berarti kemampuan variabel bebas yaitu Trust $\left(X_{1}\right)$ dan Easy Of Use $\left(\mathrm{X}_{2}\right)$ dalam menjelaskan varians dari variabel terikat yaitu minat beli ulang adalah sebesar $40,4 \%$, berarti terdapat $59,6 \%(100 \%-40,4 \%)$ varians variabel terikat yang dijelaskan oleh faktor lain yang tidak diteliti.

Secara perhitungan statistik, variabel trust menunjukkan nilai $t_{\text {hitung }}$ sebesar 1,838 yang lebih besar dari nilai $t_{\text {tabel }}=1,677$. Dengan demikian dapat disimpulkan bahwa variabel trust berpengaruh secara positif namun tidak signifikan terhadap minat beli ulang karena dilihat dari nilai signifikansi 0,072 yang lebih besar dari 0,05.

Hasil penelitian pada variabel trust memiliki tanggapan positif. Dimana indikator kemampuan (ability) pada pernyataan pertama yang berbunyi "Marketplace Shopee mempunyai kemampuan untuk mengamankan proses transaksi barang yang saya pesan dan uang yang saya transfer dengan baik" pada kuesioner memilki nilai means yang tertinggi. Artinya kemampuan marketplace Shopee dalam mengamakan transaksi yang dilakukan sudah baik dan harus dipertahankan agar tingkat kepercayaan konsumen pada marketplace shopee tetap terjaga. Namun pada indikator integritas (integrity) pada pernyataan kuesioner ketiga yang berbunyi "Marketplace Shopee memiliki detail informasi produk dengan jelas" memilki nilai mean terendah. Artinya marketplace Shopee perlu meningkatkan kejelasan informasi produk yang tersedia agar meningkatkan kepercayaan konsumen untuk bertransaksi pada marketplace Shopee. Walaupun memilki pengaruh yang positif, namun pada perhitungan uji $\mathrm{T}$ pada variabel Trust memilki nilai signifikansi yang lebih besar dari 0,05 yaitu 0,076 yang artinya pada penelitian ini, variabel Trust tidak berpengaruh signifikan atau tidak cukup besar mempengaruhi variabel dependennya yaitu minat beli ulang. Maka dapat disimpulkan bahwa $\mathrm{H}_{1}$ (Diduga Kepercayaan (Trust) Berpengaruh Signifikan Terhadap Minat Beli Ulang) ditolak.

Secara perhitungan statistik, variabel easy of use menunjukkan nilai $t_{\text {hitung }}$ sebesar 3,742 yang lebih besar dari nilai $t_{\text {tabel }}=1,677$. Dengan demikian dapat disimpulkan bahwa variabel easy of use berpengaruh secara positif dan signifikan terhadap minat beli ulang dilihat dari nilai signifikansi 0,000 yang lebih kecil dari 0,05.

Hasil penelitian pada variabel easy of use memiliki tanggapan positif. Dimana indikator easy to learn pada pernyataan pertama yang berbunyi "Aplikasi atau website Shopee mudah untuk dipelajari." pada kuesioner memilki nilai means yang tertinggi. Artinya akses website atau aplikasi dari marketplace mudah untuk dipelajari dan secara otomatis mudah untuk digunakan oleh konsumen untuk melakukan transaksi pada marketplace Shopee. Namun pada indikator easy to use pada pernyataan kuesioner keenam yang berbunyi "Aplikasi atau website Shopee mudah digunakan sehingga pengguna tidak merasa kesulitan dalam pengoperasiannya." memilki nilai mean terendah. Artinya menurut sebagian responden, marketplace Shopee perlu meningkatkan kemudahan sistemnya pada aplikasi maupun websitenya terlebih pada pengoperasian sistem pencarian sebuah produk agar konsumen dapat merasa mudah berinteraksi saat melakukan proses pencarian pada saat melakukan transaksi pada marketplace Shopee. Pada perhitungan uji T pada variabel Easy of Use memilki nilai signifikansi yang lebih kecil dari 0,05 yaitu 0,000 
yang artinya pada penelitian ini, variabel Easy Of Use berpengaruh signifikan mempengaruhi variabel dependennya yaitu minat beli ulang. Maka dapat disimpulkan bahwa $\mathrm{H}_{2}$ (Diduga Kemudahan Penggunaan (Easy Of Use) Berpengaruh Signifikan Terhadap Minat Beli Ulang) diterima.

\section{Kesimpulan Dan Saran \\ 7.1. Kesimpulan}

Setelah peneliti melakukan penelitian dan pembahasan pada bab sebelumnya mengenai Pengaruh Trust dan Easy Of Use Terhadap Minat Beli Ulang pada Marketplace Shopee di Kota Mataram maka dapat diambil kesimpulan sebagai berikut:

1. Kepercayaan (Trust) tidak berpengaruh signifikan terhadap minat beli ulang pada marketplace Shopee di Kota Mataram dilihat dari nilai signifikansi 0,072 yang lebih besar dari 0,05.

2. Kemudahan penggunaan (Easy Of Use) berpengaruh signifikan terhadap minat beli ulang pada marketplace Shopee di Kota Mataram dilihat dari nilai signifikansi 0,000 yang lebih kecil dari 0,05.

\subsection{Saran}

Berdasarkan hasil penelitian ini, maka saran yang dapat diberikan adalah sebagai berikut :

1. Saran untuk Perusahaan Shopee

Pada variabel Trust nilai mean jawaban responden yang paling kecil adalah indikator kedua pasa pernyataan kuesioner ketiga, yaitu : "Marketpace Shopee memiliki detail informasi produk dengan jelas." Artinya kepercayaan dari detail informasi produk yang ada pada marketplace Shopee masih dirasakan kurang oleh para konsumen yang menggunakan situs tersebut. Oleh karena itu, diharapkan bahwa Shopee harus meningkatkan informasi produk yang lebih jelas agar konsumen dapat lebih percaya untuk bertransaksi di marketplace Shopee. Pada variabel Easy Of Use nilai mean jawaban responden yang paling kecil adalah indikator keenam pada pernyataan keenam, yaitu : "Aplikasi atau website Shopee mudah digunakan sehingga pengguna tidak merasa kesulitan dalam pengoperasiannya." Artinya, sebagian responden merasa bahwa untuk mencari sebuah produk yang diinginkan dirasakan kesulitan. Oleh karena itu, saran yang dapat dipertimbangkan adalah perusahaan diharapkan untuk lebih memperhatikan kemudahan penggunaan pada pengoperasian sistem pencarian sebuah produk agar konsumen dapat merasa mudah berinteraksi saat melakukan proses pencarian.

2. Bagi peneliti selanjutnya, dilihat dari hasil uji R-Square hanya memperoleh $40,4 \%$ pengaruh trust dan easy of use terhadap minat beli ulang. Saran yang dapat dipertimbangkan pada penelitian selanjutnya yang ingin meneliti dapat menambahkan sampel agar penelitian lebih akurat, melakukan penelitian di wilayah lain dengan karakteristik responden yang berbeda dan dapat dijadikan sebagai referensi untuk meneliti variabel yang belum terjelaskan dalam penelitian ini. 


\section{DAFTAR PUSTAKA}

Ainurrofiq (2007). Pengaruh Dimensi Kepercayaan (Trust) Terhadap Partisipasi Pelanggan E- Commerce (Studi Pada Pelanggan E-Commerce Di Indonesia) . Tesis Universitas Brawijaya.

Apriyani, N., \& Suharti. (2017). Analisis Pengaruh Persepsi Kebermanfaatan, Persepsi Kemudahan, dan Kepercayaan Terhadap Minat Beli Ulang Pengguna Smartphone Xiaomi. Jurnal Manajemen Dewantara, 1(1), 21-34.

Asosiasi Penyelenggara Jasa Internet Indonesia (2018). https:// tekno.kompas.com .Diakses pada 19 Oktober 2018.

Assadurachman, Afif (2017). Marketplace Barang Bekas Kos Yogyakarta. Skripsi Fakultas Eknologi Industri Universitas Islam Indonesia.

Brunn, P., Jensen, M., \& Skovgaard, J. (2002). e-Marketplaces: Crafting A Winning Strategy. European Management Journal, 286-298.

Ferdinand, Augusty. (2014). Metode Penelitian Manajemen. Semarang : Penerbit Universitas Diponegoro.

Hartanto, Riadi (2018). Analisis Pengaruh Kemudahan Penggunaan, Harga, Dan Kualitas Pelayanan Terhadap Minat Pembelian Ulang Jasa Transportasi Online Pada Mahasiswa Fakultas Ekonomi Dan Bisnis Universitas Sumatera Utara . Skripsi Program Studi Strata-1 Manajemen Departemen Manajemen Fakultas Ekonomi dan Bisnis Universitas Sumatera Utara Medan.

Jogianto, Hartono (2007). Analisis dan Desain Sistem Informasi : Pendekatan Terstruktur Teori dan Praktek Aplikasi Bisnis. Yogyakarta : Penerbit Andi.

Kotler, Philip dan Lane Keller (2009). Manajemen Pemasaran. Edisi 13. Jilid 1. Jakarta : Erlangga.

Moorman,et al., (1993). "Factors Affecting Trust in Market Research Relationship". Journal Marketing Research,Vol. 57

Nasution, Fahmi Natigor. (2004). "Penggunaan teknologi Informasi Berdasarkan Aspek Perilaku (Behavioral Aspect)". Tersedia http://library.USU.ac.id/download/fe/akuntansi-fahmi2.pdf

Norhermaya, Y.A., dan Harry Soesanto (2016). Analisis Pengaruh Kepuasan Pelanggan Terhadap Kepercayaan dan Loyalitas Pelanggan untuk Meningkatkan Minat Beli Ulang (Studi Pada Online Store Lazada.Co.Id). Diponegoro Journal Of Management Volume 5, Nomor 3, Tahun 2016, Halaman 1-13.

Nurhayati., \& Wahyu, W. M. (2012). Analisis Faktor-Faktor Yang Memprngaruhi Minat Beli Ulang Masyarakat Terhadap Produk Handphone. Value Added: Vol 8, No 2. Universitas Muhammadiyah Semarang. 
Prasetyo, Sony Agung (2015). Analisis Faktor - Faktor yang Mempengaruhi Kepercayaan Serta Dampaknya Terhadap Minat Beli Ulang. Skripsi Fakultas Ekonomika Dan Bisnis Universitas Diponegoro Semarang.

Sarwono, Jonathan. (2006). Metode Penelitian Kuantitatif \& Kualitatif. Yogyakarta: Graha Ilmu.

Shopee Indonesia (2018). https:/ / id.wikipedia.org . Diakses pada 19 Oktober 2018

The Map of E-commerce in Indonesia (2018). https://iprice.co.id . Diakses pada 6 November 2018

Turban, et. al (2004). Electronic Commerce : A managerial perspective. Penerbit: Pearson Prentice Hall.

Varmaat, Shelly Cashman. (2007). Discovering Computers: Menjelajah Dunia Komputer Fundamental Edisi 3. Jakarta : Salemba Infotek.

Wong, Jony (2010). Internet Marketing for Beginners. Jakarta : Elex Media Komputindo. 